\title{
Hodgkin's disease: Bacterial etiology very probable
}

\author{
Christian Sauter* \\ Department of Medicine, University Hospital, Zürich, Switzerland
}

\begin{abstract}
Background: The etiology of Hodgkin's disease is still unknown more than 180 years after its original description. In recent years a viral etiology was the preferred hypothesis. Epidemiological, clinical, laboratory, and histological findings, however, point rather to a bacterial etiology.

Materials and methods: In the histological work-up of tissues from patients suffering from Hodgkin's disease periodic acid-Schiff (PAS) stains are routinely done. In several bacterial infections intracellular PAS-positive material can be observed.

Here ten PAS-stained slides per patient by magnifications of at least $\times 1000$ of six Hodgkin patients were examined (24 000 cells per slide).

Results: PAS-positive diastase resistant intracellular rods and spheres were found in all Hodgkin patients but not in other malignant lymphomas.

Conclusions: The diastase resistant PAS-positve structures are compatible with intracellular bacteria. After gastric MALT-lymphoma and gastric non-cardia adenocarcinoma it appears that Hodgkin's disease may also be a human tumor related to bacteria.
\end{abstract}

\section{Introduction}

During the last few years the discussion about the bacterial etiologies of malignant tumors was revived. In Xenopus a mycobacterium was shown to be related to a lymphosarcoma [1]. In mice a helicobacter species was found to be a likely candidate for the etiology of hepatocellular tumors [2]. A connection of bacteria to human neoplasms was shown for gastric MALT-lymphoma [3-5] and for gastric non-cardia adenocarcinoma, where Helicobacter pylori has been accepted as a definite biological carcinogen by the WHO / IARC [6]. Some benign human tumors are also related to bacteria such as cutaneous bacillary angiomatosis (Bartonella, formerly Rochalimaea quintana) [7], or benign lymphomas (Bartonella henselae) [8]. Agrobacterium tumefaciens is known to induce malignant tumors in plants [9]. The relationship now being established between bacteria and certain plant, animal, and human malignant tumors there is the question arising, if there are more tumors where bacteria might play an etiological role. It is proposed that the pathogenesis of Hodgkin's disease is similar to the one of crown gall tumors in plants [10], where a natural exchange of genetic material from Agrobacterium tumefaciens (oncogenic plasmids) to plant cells induces malignant tumors in dicotyledones [11]. The "crown gall" hypothesis for Hodgkin's disease would explain the clinical observations of a bacterial infection and the behaviour as a malignant tumor. In addition regression of Hodgkin's disease by antibiotics has been described [12].

Periodic acid-Schiff (PAS) staining is known to be an important clue to the histological identification of intracellular bacteria such as Tropheryma whipplei [13]. In the histological work-up of tissue of malignant lymphomas periodic acid-Schiff (PAS) stains are routinely done, but were not examined at magnifications above $\times 400$ where bacteria could be detected. Ten PAS-stained slides at a magnification of at least $\times 1000$ of six patients suffering from Hodgkin's disease were screened.

\section{Methods}

Ten PAS-stained slides of six Hodgkin patients were screened for PAS-positive intracellular structures at a magnification of $\times 1000$ (oil immersion); at least 2400 cells in each slide were examined.

\section{Results}

PAS-positive diastase-resistant intracellular rods and spheres could be observed in Hodgkin's disease. Figures 1-3 show the rods and the spheres. The rods are about $3 \mu \mathrm{m}$ in length and $0.5 \mu \mathrm{m}$ in width.

\section{Discussion}

In 1995 Christian Sauter put forward the hypothesis that Hodgkin's diasease is a human counterpart of bacterially induced crown-gall tumors in plants [10], where Agrobacterium tumefaciens is the etiologic agent [9]. In Hodgkin's disease many features remind of a bacterial infection: Ever since the first description of Hodgkin's disease the search for etiological agents including bacteria and fungi was intensive but unsuccessful. A viral etiology was thought more probable when Epstein-Barr virus DNA was detected in Hodgkin's disease tissue [14]. Epidemiological, clinical, laboratory, histological and treatment features, however, point rather to a bacterial etiology (Table 1).

\section{Epidemiology}

Two main epidemiological patterns are found in Hodgkin's disease: 1. In developing countries a first peak is found in childhood, a low

${ }^{\star}$ Correspondence to: Christian Sauter, Department of Medicine, University Hospital, Zürich, Switzerland, Tel: +41 44311 9872, E-mail: cesauter@bluewin.ch

Key words: hodgkin's disease, etiology, bacteria

Received: January 27, 2019; Accepted: February 06, 2019; Published: February 11,2019 
incidence in the third decade, and a second peak in older adults [15]. 2. In industrialized countries a low incidence is observed in children, a first peak in young adults and a second one in older adults. These epidemiological patterns may remind of a bacterial disease such as tuberculosis. Epidemiological studies by Vianna et al. [16] suggest an incubation time of years like for lepra.

\section{Presentation}

In over $90 \%$ of Hodgkin patients the disease manifests itself in lymph nodes draining the respiratory tract [17]. With this pattern of presentation an airborne infection is quite probable.

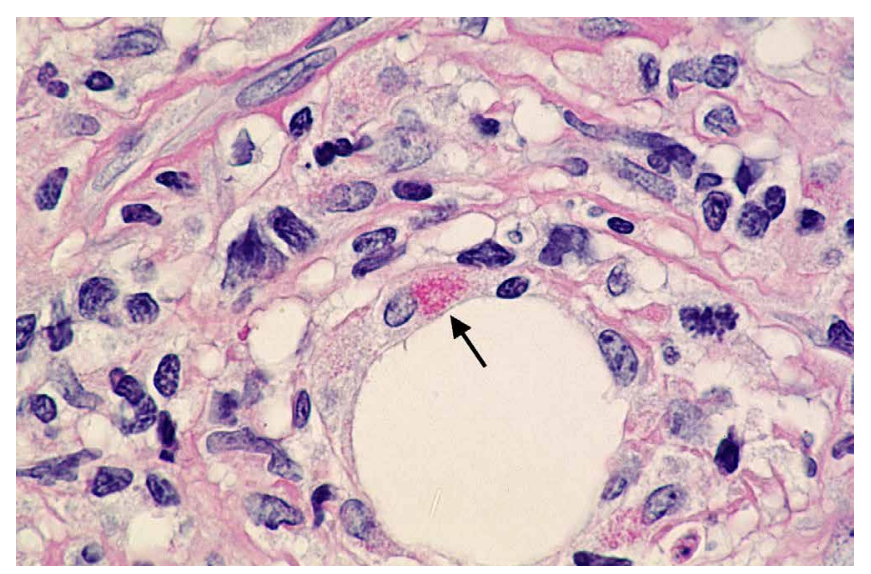

Figure 1. Intracellular rods; $\times 1000$ (arrow)

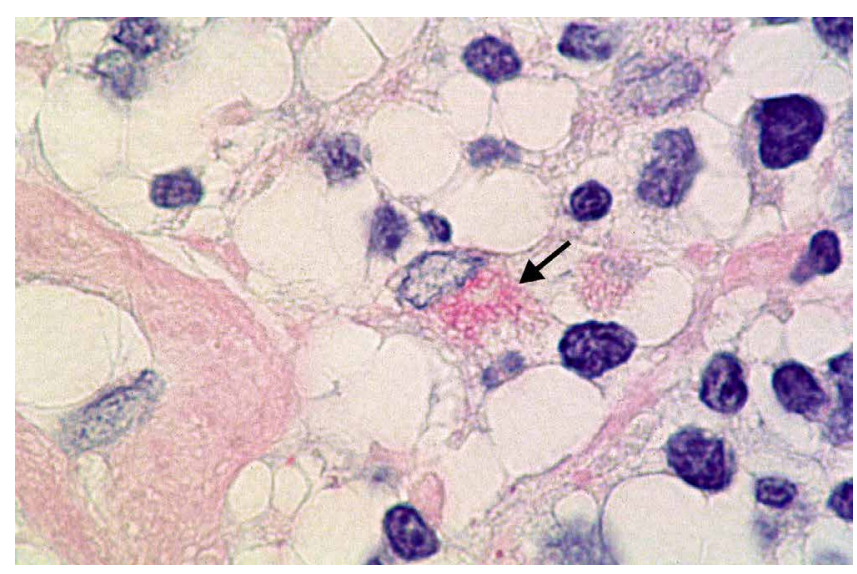

Figure 2. Intracellular rods $\times 2000$ (arrow)

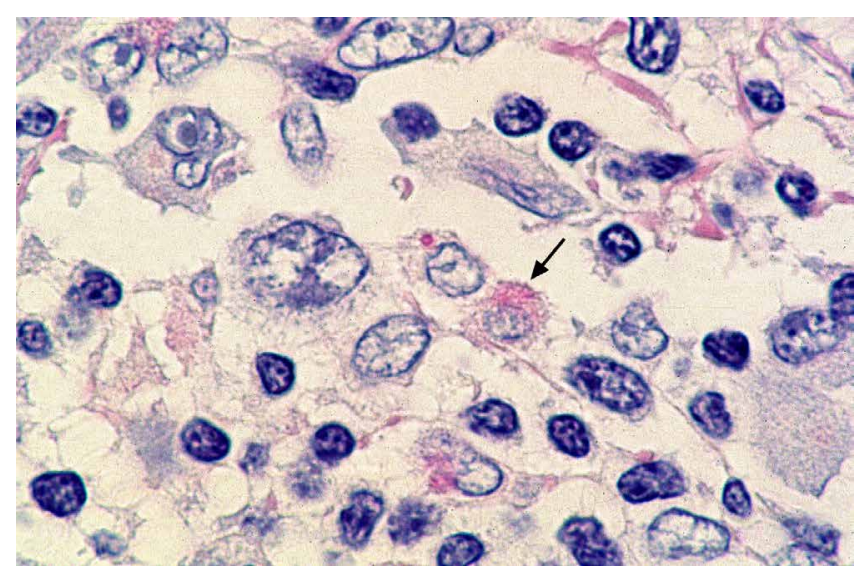

Figure 3. Intracellular rods (arrow) and sphere $\times 2000$
Table 1. Hodgkin's disease: Frequent observations pointing to a bacterial infection $(+)$. These findings are uncommon (-) in a so called true neoplasme

\begin{tabular}{|l|c|c|}
\hline & Hodgkin's disease & True neoplasm \\
\hline Epidemiology & + & - \\
\hline Transmission & + & - \\
\hline Symptoms & + & - \\
\hline Fever & + & - \\
\hline Chills & & \\
\hline Night sweats & + & - \\
\hline Presentation & & - \\
\hline $130 \%$ in respiratory tract lymph nodes & + & - \\
\hline Laboratory findings & + & - \\
\hline High blood sedimentation rate & + & - \\
\hline Elevation 01C-reactive-protein (CRP) & + & - \\
\hline $\begin{array}{l}\text { Neutropoilia (with signs of bacterial } \\
\text { Infection) }\end{array}$ & + & \\
\hline Lymphopenia (CD 4 cells decreased) & & - \\
\hline Monocylosis & + & \\
\hline Histology & & \\
\hline No coherent tumor cell population & & \\
\hline
\end{tabular}

\section{Symptoms and laboratory findings}

The fluctuating fever, chills, and night-sweats as observed in Hodgkin patients are most typical of a chronic bacterial infection. The laboratory findings (neutrophilia, increased blood sedimentation rate and elevated C-reactive protein concentrations) point in the same direction.

\section{Histology}

In contrast to "true" neoplasms there is no coherent tumor cell population. A mixture of lymphocytes, macrophages, eosinophils, plasma cells, fibroblasts, and others is found in the tissue affected by Hodgkin's disease. Hodgkin / Reed-Sternberg cells which are believed to be the malignant cell population represent only about $0.1 \%$ to $1 \%$ [18]. The histological picture is rather compatible with a granuloma as seen in chronic bacterial infections than with "true" neoplasms.

\section{Treatment}

Hodgkin's disease is successfully treated by radiotherapy and chemotherapy. Is this success compatible with a bacterial etiology? One thinks it is at least in early Hodgkin's disease. Prior to the use of antibiotics localised infections were successfully treated by radiotherapy [19]. Cytotoxic drugs used in the treatment of Hodgkin's disease show antibacterial activity [20]. The C-reactive protein (CRP) is typically elevated in bacterial infections and Hodgkin's disease. After the implementation of a successful antibiotic treatment of a bacterial infection the CRP serum-level decreases by about $50 \%$ within 24 hours [21]. The CRP serum-concentration during the first days of a successful chemotherapy of Hodgkin's disease shows a similar kinetic [22].

The dimensions of the intracellular rods which was observed (about $3 \mu \mathrm{m}$ in length and $0.5 \mu \mathrm{m}$ in width) and the diastase-resistant PAS-positivity are compatible with several groups of bacteria such as the $a-2$ subgroup of proteobacteria: Bartonella is related to benign human tumors including lymphomas. Agrobacterium tumefaciens belonging to the same subgroup of proteobacteria is known to induce malignant tumors in plants [9]. The PAS-positive spheres one interprets as accumulation of bacterial residues in phagosomes as in Tropheryma whipplei infections.

In conclusion it is proposed that bacteria play an etiological role in Hodgkin's disease We thank Regula Rüegg for photographic assistance and Elisabeth Sauter for linguistic help. 


\section{References}

1. Asfari M (1988) Mycobacterium-induced infectious granuloma in Xenopus: histopathology and transmissibility. Cancer Res 48: 958-963. [Crossref]

2. Ward JM, Fox JG, Anver MR, Haines DC, George CV, et al. (1994) Chronic active hepatitis and associated liver tumors in mice caused by a persistent bacterial infection with a novel Helicobacter species. J Natl Cancer Inst 86: 1222-1227. [Crossref]

3. Husell T, Isaacson PG, Crabtree JE, Spencer J (1993) Cells from low-grade B-cell gastric lymphoma of mucosa-associated lymphoid tissue proliferate in response to Helicobacter pylori. Lancet 342: 571-574.

4. Wotherspoon AC, Doglioni C, Diss TC, Pan L, Moschini A, et al. (1993) Regression of primary low-grade B-cell lymphoma of mucosa-associated lymphoid tissue after eradication of Helicbacter pylori. Lancet 342: 575-577. [Crossref]

5. Stolte M, Eidt S (1993) Healing gastric maltoma by eradication of H pylori? Lancet 342: 568 .

6. Logan RPH (1994) Helicobacter pylori and gastric cancer. Lancet 344: 1078 -1079.

7. Koehler JE, Quinn FD, Berger TG, Le Boit PE, Tappero JW (1992) Isolation of Rochalimaea species from cutaneous and osseous lesions of bacillary angiomatosis. $N$ Engl J Med 327: 1625-1631. [Crossref]

8. Dolan MJ, Wong MT, Regnery RL, Jorgensen JH, Garcia M, et al. (1993) Syndrome of Rochalimaea henselae adenitis suggesting cat scratch disease. Ann Intern Med 118 : 331-336. [Crossref]

9. Caplan A, Herrera-Estrella L, Inzé D, Haute EV, Montagu MV, et al. (1983) Introduction of genetic material into plant cells. Science 222: 815-821.

10. Sauter C (1995) Is Hodgkin's disease a human counterpart of bacterially induced crown-gall tumours? Lancet 346: 1433. [Crossref]

11. Yusibov VM, Steck TR, Gupta V, Gelvin SB (1994) Association of single-stranded transferred DNA from Agrobacterium tumefaciens with tobacco cells. Proc Natl Acad Sci USA 91: 2994-2998. [Crossref]
12. Sauter Chr, Blum S (2002) Regression of lung lesions in Hodgkin's disease by antibiotics: case report and hypothesis on the etiology of Hodgkin's disease. Am J Clin Oncol 26: 92-94. [Crossref]

13. Walter R, Bachmann SP, Schaffner A, Rüegg R, Schoedon G (2001) Bone marrow involvement in Whipple's disease: rarely reported, but really rare? Brit J Haemat 112: 677-679. [Crossref]

14. Weiss LM, Strickler JG, Warnke RA, Purtilo DT, Sklar J (1987) Epstein-Barr vira DNA in tissues of Hodgkin's disease. Am J Pathol 129: 86-91. [Crossref]

15. Correa P, O'Connor GT (1971) Epidemiologic patterns of Hodgkin's disease. Int J Cancer 8: 192-201. [Crossref]

16. Vianna NJ, Polan AK (1973) Epidemiologic evidence for transmission of Hodgkin's disease. New Engl J Med 289: 499-502. [Crossref]

17. DeVita VT, Hellman S, Jaffe ES (1993) Hodgkin's disease. In: DeVita VT, Hellman S, Rosenberg SA, (Edtr). Cancer; principles and practices of oncology. ( $4^{\text {th }}$ Edn). Philadelphia, JB Lippincott: 1828.

18. Kaplan HS (1980) Hodgkin's disease. ( $2^{\text {nd }}$ Edn). Cambridge, Harvard University Press 52-115.

19. Hassenstein E (1976) Strahlenbehandlung entzündlicher Erkrankungen - heute nochindiziert. Med Klin 71: 1117-1119.

20. Bronzetti G, Zeiger E, Malling HV (1979) Genetic toxicity of procarbazine in bacteria and yeast. Mutat Res 68: 51-58. [Crossref]

21. Baltz M, Rowe IF, Pepys MB (1985) In vivo turnover studies of C-reactive protein. Clin Exp Immunol 59: 243-250. [Crossref]

22. Lippuner T, Sauter C (1993) Course of C-raective protein (CRP) in the first days of chemotherapy for Hodgkin's disease: possible clue to the etiology. Proc Amer Soc Clin Oncol 12: 367.

Copyright: (C2019 Sauter C. This is an open-access article distributed under the terms of the Creative Commons Attribution License, which permits unrestricted use, distribution, and reproduction in any medium, provided the original author and source are credited. 